\title{
rAAV-CFTR $\Delta$ R Rescues the Cystic Fibrosis Phenotype in Human Intestinal Organoids and Cystic Fibrosis Mice
}

\author{
Dragana Vidović ${ }^{1 *}$, Marianne S. Carlon ${ }^{1 \star}$, Mélanie F. da Cunha ${ }^{2 \ddagger}$, Johanna F. Dekkers ${ }^{3,4 \ddagger}$, Monika I. Hollenhorst ${ }^{2}$, \\ Marcel J. C. Bijvelds ${ }^{5}$, Anabela S. Ramalho ${ }^{6}$, Chris Van den Haute ${ }^{7,8}$, Marc Ferrante ${ }^{9}$, Veerle Baekelandt ${ }^{7}$, \\ Hettie M. Janssens ${ }^{10}$, Kris De Boeck ${ }^{11}$, Isabelle Sermet-Gaudelus ${ }^{2}$, Hugo R. de Jonge ${ }^{5}$, Rik Gijsbers ${ }^{1,8 \S}$, \\ Jeffrey M. Beekman ${ }^{3,4 \S}$, Aleksander Edelman ${ }^{2 \S}$, and Zeger Debyser ${ }^{1 *}$ \\ ${ }^{1}$ Molecular Virology and Gene Therapy, ${ }^{6}$ Stem Cell Biology and Embryology, ${ }^{7}$ Neurobiology and Gene Therapy, ${ }^{8}$ Leuven Viral Vector \\ Core, and ${ }^{9}$ Translational Research in Gastrointestinal Disorders, KU Leuven, Flanders, Belgium; ' 2 INSERM U1151, University Paris \\ Descartes, Faculté de Médecine Necker Enfants-Malades, Paris, France; ${ }^{3}$ Department of Pediatric Pulmonology, Wilhelmina Children's \\ Hospital, and ${ }^{4}$ Laboratory of Translational Immunology, University Medical Center, Utrecht, the Netherlands; ${ }^{5}$ Department of \\ Gastroenterology and Hepatology, Erasmus University Medical Center, Rotterdam, the Netherlands; ${ }^{10}$ Department of Pediatric \\ Pulmonology, Erasmus University Medical Centre/Sophia Children's Hospital, Rotterdam, the Netherlands; and ${ }^{11}$ University Hospital \\ Leuven, Flanders, Belgium
}

\section{Abstract}

Rationale: Gene therapy holds promise for a curative mutationindependent treatment applicable to all patients with cystic fibrosis (CF). The various viral vector-based clinical trials conducted in the past have demonstrated safety and tolerance of different vectors, but none have led to a clear and persistent clinical benefit. Recent clinical breakthroughs in recombinant adeno-associated viral vector (rAAV)based gene therapy encouraged us to reexplore an rAAV approach for CF.

Objectives: We evaluated the preclinical potential of rAAV gene therapy for CF to restore chloride and fluid secretion in two complementary models: intestinal organoids derived from subjects with CF and a CF mouse model, an important milestone toward the development of a clinical rAAV candidate for CF gene therapy.

Methods: We engineered an rAAV vector containing a truncated CF transmembrane conductance regulator $(\mathrm{CFTR} \Delta \mathrm{R})$ combined with a short promoter (CMV173) to ensure optimal gene expression.
A rescue in chloride and fluid secretion after rAAV-CFTR $\Delta$ R treatment was assessed by forskolin-induced swelling in CF transmembrane conductance regulator (CFTR)-deficient organoids and by nasal potential differences in $\Delta \mathrm{F} 508$ mice.

Measurements and Main Results: rAAV-CFTR $\Delta$ R transduction of human CFTR-deficient organoids resulted in forskolin-induced swelling, indicating a restoration of CFTR function. Nasal potential differences demonstrated a clear response to low chloride and forskolin perfusion in most $\mathrm{rAAV}$-CFTR $\Delta \mathrm{R}$-treated CF mice.

Conclusions: Our study provides robust evidence that rAAVmediated gene transfer of a truncated CFTR functionally rescues the CF phenotype across the nasal mucosa of CF mice and in patientderived organoids. These results underscore the clinical potential of $\mathrm{rAAV}-\mathrm{CFTR} \Delta \mathrm{R}$ in offering a cure for all patients with CF in the future.

Keywords: gene therapy; airways; patient-derived organoid cultures; viral vectors; nasal potential difference

(Received in original form May 11, 2015; accepted in final form September 30, 2015)

*These authors contributed equally to this work (shared first authorship).

‡These authors contributed equally to this work (shared second authorship).

§These authors contributed equally to this work (shared second-to-last authorship).

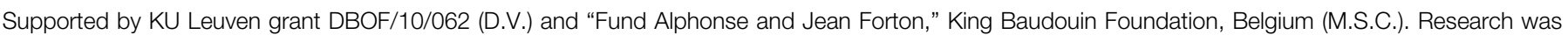
funded by IWT-Vlaanderen (SBO Myriad) and by the IMIR program from KU Leuven. D.V. and M.S.C. are recipients of travel grants from the European

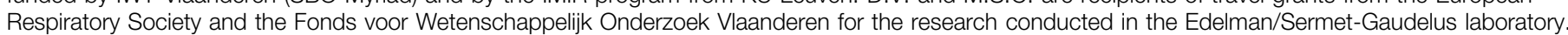

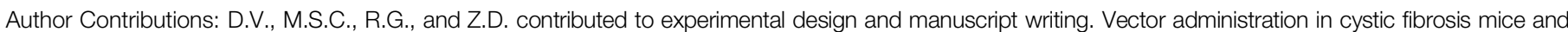

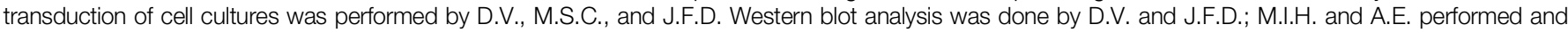

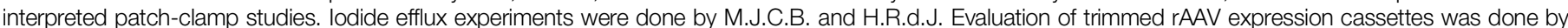

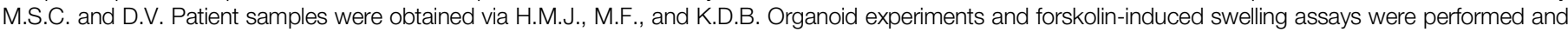

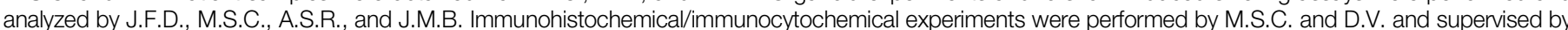

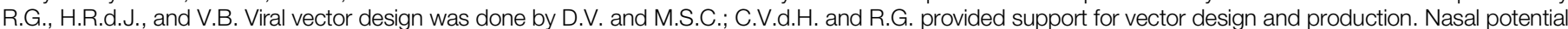

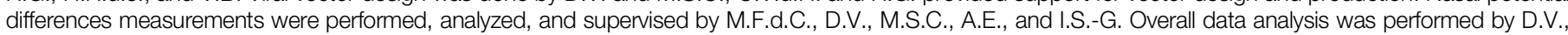
M.S.C., J.F.D., M.F.d.C., M.J.C.B., and M.I.H. Data interpretation came from Z.D., R.G., H.R.d.J., A.E., I.S.-G., J.M.B., C.V.d.H., and V.B.

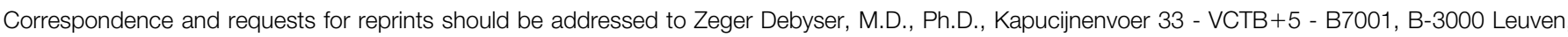
Flanders, Belgium. E-mail: zeger.debyser@med.kuleuven.be

This article has an online supplement, which is accessible from this issue's table of contents at www.atsjournals.org

Am J Respir Crit Care Med Vol 193, Iss 3, pp 288-298, Feb 1, 2016

Copyright $@ 2016$ by the American Thoracic Society

Originally Published in Press as DOI: 10.1164/rccm.201505-0914OC on October 28, 2015

Internet address: www.atsjournals.org 


\section{At a Glance Commentary}

\section{Scientific Knowledge on the}

Subject: The modest successes of previous clinical trials for cystic fibrosis (CF) gene therapy raise the question of how to further improve gene transfer efficacy and how to more accurately determine functionality of $\mathrm{CF}$ transmembrane conductance regulator (CFTR)-encoding vectors in preclinical studies. Organoid experiments are valuable because they allow functional vector assessment in CF patientderived material using a sensitive and quantitative swelling assay. The $\mathrm{CF}$ mouse model complements the organoid data because a potential rescue of the $\mathrm{CF}$ phenotype can be assessed in vivo by nasal potential differences, a widely accepted biomarker used for evaluation of response to treatment in patients with CF.

\section{What This Study Adds to the}

Field: In the process of developing a clinical candidate for CF viral vectorbased gene therapy, a thorough examination of preclinical efficacy in relevant cell and animal models is a prerequisite. Here we describe that a single dose of a therapeutic vector, recombinant adeno-associated viral vector-truncated CFTR, rescues the CF phenotype in intestinal organoids derived from subjects with $\mathrm{CF}$ and in the nasal mucosa of CF mice, highlighting its clinical potential to correct both respiratory and gastrointestinal pathology in CF. These results pave the way to assess long-term efficacy and functional restoration of CFTR activity in a large animal model recapitulating human CF pathology.

Cystic fibrosis (CF) is caused by mutations in CFTR, which codes for the CF transmembrane conductance regulator protein (CFTR), a chloride/bicarbonate channel regulating fluid transport across epithelia. Almost 2,000 mutations have been described (www.genet.sickkids.on.ca). The major clinical manifestations of CF are related to respiratory and gastrointestinal tract pathology. In 2012, a breakthrough in
CF therapy was achieved with the U.S. Food and Drug Administration approval of the first curative drug (Kalydeco; Vertex Pharmaceutics, Cambridge, MA), a potentiator correcting the CFTR gating defect (www.ema.europa.eu). It can, however, only be applied to $4-5 \%$ of patients with CF carrying gating mutations. Very recently the U.S. Food and Drug Administration approved the first therapy, which tackles the underlying defect of the most common CF-causing mutation $(\Delta \mathrm{F} 508)$ with a combination of a CFTR potentiator (Kalydeco, ivacaftor) and a CFTR corrector (lumacaftor), a drug that partially rescues $\Delta$ F508-CFTR trafficking to the membrane (1). In a phase III clinical trial this combination therapy resulted in a significant, albeit modest (2.6-4\%) improvement in lung function in patients with CF homozygous for the $\Delta \mathrm{F} 508$ mutation (2), underscoring the need for further development of more potent therapeutic strategies.

In contrast to small molecules that act mutation-specific (3), gene therapy offers a mutation-independent treatment for all patients with $\mathrm{CF}$, with the potential to cure the disease. In the early 1990s, clinical trials using adenoviral and recombinant adenoassociated viral vectors (rAAV2/2) did not improve lung function (4-6). Recent successes in gene therapy using rAAV to treat congenital blindness, hemophilia $B$, and lipoprotein lipase deficiency encouraged us to reexplore rAAV gene therapy for CF (reviewed in Reference 7). rAAV is derived from wild-type AAV and not associated with human pathology. It has emerged as a promising and safe vector because of its low immunogenicity, nonintegrating nature, and absence of viral genes (8). In 2012, the European Medicines Agency approved the first rAAV gene therapy product (Glybera; UniQure, Amsterdam, the Netherlands) for patients with lipoprotein lipase deficiency (www.ema.europa.eu). Unlike rAAV clinical trials in the past (9), our approach uses rAAV2/5, an airway-tropic serotype (10-12). Additionally, we incorporate a truncated CFTR (CFTR $\Delta$ R) that allows insertion of a promoter to enhance gene expression. $\mathrm{CFTR} \Delta \mathrm{R}$ has a deletion in the regulatory domain $(\Delta 708-759)$ but retains channel activity (13).

We investigated the therapeutic potential of $\mathrm{rAAV}-\mathrm{CFTR} \Delta \mathrm{R}$ in two complementary models: intestinal organoids derived from subjects with
$\mathrm{CF}$ and a CF mouse model. Human intestinal organoids are primary stem cell-based cultures generated from rectal biopsies (14-16). CFTR activation leads to rapid volumetric expansion of organoids $(17,18)$, providing a platform to study CFTR function following CFTR gene transfer. Here we report that viral vector-mediated gene transfer results in a rescue of the $\mathrm{CF}$ phenotype in human CFTR-deficient organoids.

Finally, we evaluated rAAV2/5CFTR $\Delta$ R gene therapy efficacy in CF mice homozygous for the $\Delta$ F508 mutation (19). We assessed a possible CFTR correction in airways by measuring in vivo nasal potential differences (NPDs), because the nasal epithelium of CF mice mimics transepithelial ion transport defects observed in patients with CF (20). We demonstrate that a single dose of rAAV2/5-CFTR $\Delta \mathrm{R}$ could restore $\mathrm{Cl}^{-}$ conductance. Taken together, our results underscore the therapeutic potential of $\mathrm{rAAV}$-CFTR $\Delta \mathrm{R}$ as gene therapy vector for $\mathrm{CF}$, opening new avenues toward a generic cure for all patients. Some of the results of these studies have been previously reported in the form of abstracts (21-23).

\section{Methods}

\section{Viral Vector Production}

Production of lentiviral vector (LV) and rAAV was performed as described previously with minor modifications $(12,24$, $25)$. Vector production and cloning strategies are provided in the online supplement.

\section{Generation of HeLa Cell Lines Stably Expressing CFTR Constructs}

HeLa cells stably overexpressing triple flag (3F)-tagged CFTR constructs were generated by transduction with vesicular stomatitis virus glycoprotein G (VSV-G) pseudotyped LV encoding the transgene of interest under the control of the human cytomegalovirus (CMV) promoter.

\section{Detection of CFTR Expression}

Detailed protocols and antibodies used for Western blotting, immunocytochemical, and immunohistochemical analysis are available in the online supplement. 


\section{lodide Efflux Assay}

The assay was performed as described previously with minor modifications provided in the online supplement (26).

\section{Patch Clamp}

Whole-cell patch-clamp analysis was performed as described previously with minor modifications provided in the online supplement (27).

\section{Transduction of Human Intestinal Organoids}

The Ethics Committee of the University Medical Center Utrecht approved this study, and informed consent was obtained. Organoids were generated from rectal biopsies and cultured as described previously $(14,18)$. For viral vector transduction, cultures were trypsinized (TrypLE; Gibco $\mathrm{BRL}$, Invitrogen, Merelbeke, Belgium) and seeded in 96-well plates in $4 \mu \mathrm{l}$ Matrigel (Corning, Corning, NY) and viral vector (1:1) containing single cells and small organoid fragments. These cells were incubated at $37^{\circ} \mathrm{C}(10 \mathrm{~min}$ for $\mathrm{LV} ; 30 \mathrm{~min}$ for rAAV) and immersed in medium. rAAV transduction efficiency was verified by measuring Firefly luciferase (Fluc) activity after addition of $50 \mathrm{mM}$ D-luciferin using an IVIS Spectrum (Xenogen; Caliper LS, Hopkinton, MA). Quantification of forskolin-induced organoid swelling (FIS) was performed as described previously (18). A detailed protocol is available in the online supplement.

\section{Mouse Model and Viral Vector Administration}

Adult FVB/N mice homozygous for the $\Delta$ F508 mutation (Cftr ${ }^{\text {tm1Eur }}$ mice) (19) were obtained from CDTA (Cryopréservation, Distribution, Typage et Archivage animal) (Orléans, France) and housed on a fiberfree diet. A total of $50 \mu$ l of vector suspension $\left(9 \times 10^{10} \mathrm{GC} /\right.$ animal) rAAV2/ 5 -CFTR $\Delta$ R or control rAAV2/5-eGFPP2A-Fluc was administered by nasal instillation to anesthetized mice. All animal procedures were approved by the local ethical committee in compliance with European Community regulations.

\section{NPD Measurements}

CFTR activity in the nasal epithelium of $\Delta$ F508 mice was assessed by NPD as described previously with minor modifications provided in the online supplement (28).

\section{Statistical Analysis}

For NPD measurements, response to vector treatment between groups was compared by Mann-Whitney test for unpaired observations. A $P$ value less than 0.05 was considered statistically significant $\left({ }^{*} P<\right.$ $\left.0.05,{ }^{* *} P<0.01\right)$. GraphPad Prism 5 (GraphPad Software, San Diego, CA) software was used for statistical analysis.

\section{Results}

\section{CFTR Truncated in the Regulatory Domain (CFTR $\Delta R$ ) Is a Functional and Regulatable Chloride Channel}

rAAV has a limited packaging capacity and the full-length CFTR complementary DNA (cDNA) does not fit the small vector. As a first step in the development of a rAAVbased gene therapy for CF, we evaluated and compared functionality of two truncated versions of CFTR with that of the full-length CFTR channel. We generated HIV-based LVs that carry the 3F-tagged full-length CFTR cDNA (4,443 bp), CFTR $\Delta$ N (3,729 bp, $\Delta 27-264$, missing the first four transmembrane segments at the $\mathrm{N}$ terminus) (29), or CFTR $\Delta \mathrm{R}(4,287 \mathrm{bp}$, lacking residues 708-759 of the regulatory R-domain) (30) (Figure 1A) and generated stable HeLa cell lines. The subcellular distribution of CFTR $\Delta \mathrm{R}$ was comparable with that of full-length CFTR as shown by immunocytochemistry (Figure 1B). By Western blot analysis, we could demonstrate that the expression level of CFTR $\Delta \mathrm{R}$ was similar to that of full-length CFTR, showing the immature protein (band B) and the glycosylated, fully mature protein (band C) (Figure 1C). In contrast, 3 F-CFTR $\Delta \mathrm{N}$ showed only a single band on Western blot and located mainly to the cytoplasm (Figures $1 \mathrm{~B}$ and $1 \mathrm{C}$ ).

Next, we compared functionality of the respective CFTR versions in an iodide $\left({ }^{125} \mathrm{I}^{-}\right)$ efflux assay (Figure 1D). ${ }^{125} \mathrm{I}^{-}$efflux increased in cells expressing 3F-CFTR $\Delta \mathrm{R}$ after exposure to a mixture of forskolin and genistein (indicated by an arrow), comparable with that of full-length 3F-CFTR-expressing cells, whereas no ${ }^{125} \mathrm{I}^{-}$efflux was observed for 3FCFTR $\Delta \mathrm{N}$ cells or nontransduced HeLa cells (Figure 1D, negative). The fact that ${ }^{125} \mathrm{I}^{-}$ efflux was only observed after activation of adenylyl cyclase activity by forskolin underscores that CFTR $\Delta \mathrm{R}$ is regulated by the cAMP/protein kinase A pathway and has no constitutive activity.
Next, we evaluated 3F-CFTR $\Delta$ R and fulllength 3F-CFTR protein function by wholecell patch-clamp analysis (Figures 1E-1G). Protein expression was verified by Western blot (see Figure E1 in the online supplement). Currents were recorded both under basal conditions to control for constitutive channel activity and following CFTR activation with a cAMP agonist cocktail. The presence of a CFTR-specific current $\left(\Delta \mathrm{I}_{\mathrm{CFTR}}\right)$ was evaluated by using inh172, a CFTR inhibitor (Figures $1 \mathrm{E}-1 \mathrm{G})(31)$. For $3 \mathrm{~F}-\mathrm{CFTR} \Delta \mathrm{R}$ cells, only a very low current was detectable under basal conditions demonstrating absence of constitutive CFTR $\Delta \mathrm{R}$ activity. Interestingly, $\Delta \mathrm{I}_{\mathrm{CFTR}}$ generated by CFTR $\Delta \mathrm{R}$ was comparable with that of full-length CFTR (Figure 1G), consistent with the results from the ${ }^{125} \mathrm{I}^{-}$efflux assay (Figure 1D) and in line with earlier reports (13).

\section{CFTR $\Delta R$ Restores Chloride and Fluid Secretion in Intestinal Organoids Derived from Subjects with CF}

After showing functionality in a HeLa-based cell culture model, we set out to evaluate the potential of CFTR $\Delta \mathrm{R}$ to rescue the CF phenotype in human CFTR-deficient organoids (E60X/4014delATTT; referred to as $\mathrm{CF}$ ) and to compare activity with full length 3F-CFTR. CF organoids were transduced with LVs encoding CFTR $\Delta \mathrm{R}$, full-length CFTR, or a vector encoding a reporter gene (eGFP) to control for possible transduction-related side effects and monitored for CFTR activity using the FIS assay (Figures 2A-2C). Healthy control organoids, expressing endogenous levels of CFTR and transduced with an eGFP-control vector, were included as a reference. In LV$\mathrm{CFTR} \Delta \mathrm{R}$ transduced $\mathrm{CF}$ organoids, forskolin addition resulted in a strong increase in organoid swelling (50\% increase after 120 min; compare with $t=0 \mathrm{~min}$ ), in line with the rescue observed for LV-CFTR transduced CF organoids (Figure 2B). Similar results were obtained at lower vector doses (see Figure E2). Compared with nontransduced CF organoids, a sixfold increase in organoid swelling (i.e., area under the curve obtained from time periods measured in Figure 2B) was reached after correction with LV$\mathrm{CFTR} \Delta \mathrm{R}$ and a fivefold increase after correction with LV-CFTR (Figure 2C). Truncated and full-length CFTR proteins migrated at the predicted molecular weight as detected by Western blot analysis, albeit at lower expression levels than the endogenous CFTR expressed in healthy control organoids 


\section{A}

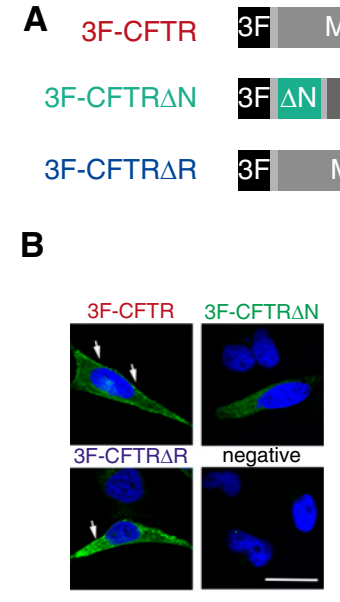

MSD1

NBD1 R-domain

MSD2

NBD2

BD1 R-domain

\section{MSD2 NBD2}

MSD1

NBD1

$\Delta R$

MSD2

\section{NBD2}

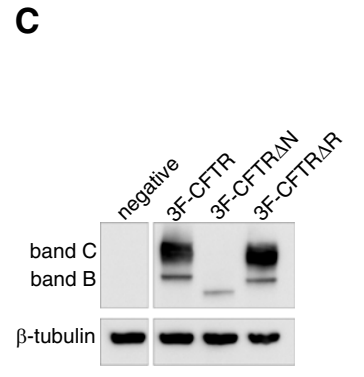

$\begin{aligned} \text { D } & \rightarrow \text { 3F-CFTR } \\ & -3 \text { F-CFTR } \Delta \text { R }\end{aligned}$

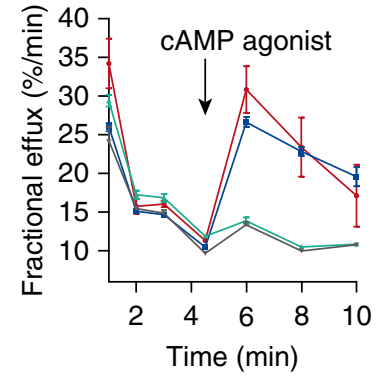

E

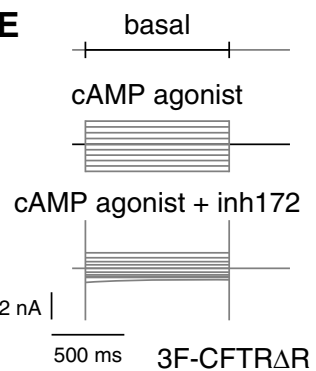

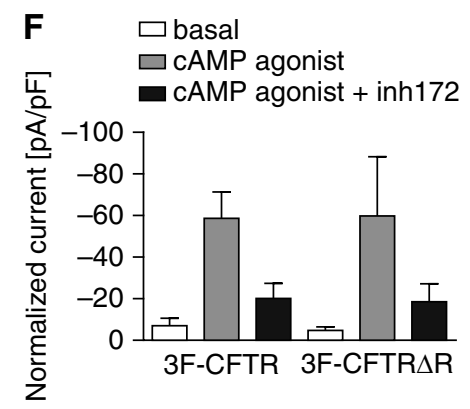

G

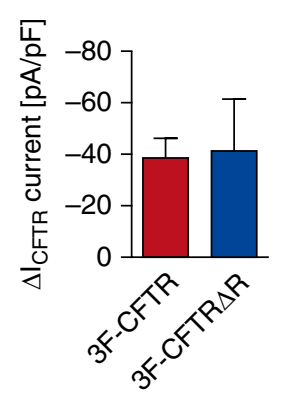

Figure 1. Functional validation of trimmed cystic fibrosis transmembrane conductance regulator (CFTR) constructs. (A) Overview of triple flag-tagged (3F) CFTR constructs: 3F-CFTR and two 3F-truncated CFTR constructs (CFTR $\Delta N$ and CFTR RR). (B) Immunocytochemistry of HeLa cells transduced with lentiviral vectors expressing indicated CFTR constructs. Anti-CFTR-Alexa-488 staining visualized CFTR-positive cells (green); 4',6-diamidino-2-phenylindole-stained nuclei (blue). Arrows indicate membrane localization. Scale bar $=25 \mu \mathrm{m}$. (C) Western blot analysis of CFTR (anti-flag antibody) and $\beta$-tubulin (loading control) in whole-cell lysates of transduced HeLa cells. Band B shows immature CFTR protein and band $C$ the glycosylated, fully mature protein. $(D)$ lodide $\left({ }^{125} I^{-}\right)$efflux in HeLa cells transduced with the indicated CFTR constructs. Arrow depicts time point of CFTR activation by forskolin and genistein. (E) A representative recording of whole-cell patch clamp in HeLa-3F-CFTR $\Delta$ R cells. (F) Quantification of whole-cell currents before activation, on activation with a cAMP-analog and 3-isobutyl-1-methylxanthine (referred to as CAMP agonist), and subsequent addition of CFTR inhibitor (inh172) in monoclonal HeLa cells 3F-CFTR $(n=8)$ and 3F-CFTR $\Delta R(n=5)$. (G) Quantification of CFTR-mediated current $\left(\Delta \mathrm{I}_{\text {CFTR }}\right)$ calculated by subtracting the current after addition of inh172 from the current obtained on activation. Measured currents were normalized to cell capacitance. All data are depicted as mean + SEM. MSD = membranespanning domain; $\mathrm{N}=\mathrm{N}$ terminus; $\mathrm{NBD}=$ nucleotide-binding domain; R-domain = regulatory domain.

(Figure 2D). Altogether, these results strengthen the data obtained in the ${ }^{125} \mathrm{I}^{-}$ efflux assay and the patch-clamp analyses (Figure 1), and demonstrate that CFTR $\Delta \mathrm{R}$ rescues $\mathrm{Cl}^{-}$secretion to similar levels as observed for the full-length protein.

\section{Optimization of Trimmed Expression Cassettes to Accommodate CFTR $\Delta R$} Because the rAAV genome size is limited to $5 \mathrm{~kb}$, this excludes the addition of the full- length CFTR cDNA in combination with regulatory elements. We opted for a truncated CFTR (CFTR $\Delta$ R), which allows insertion of an additional promoter to enhance gene expression levels. We evaluated a shortened version of the CMV promoter (comprising $173 \mathrm{bp}$ of the fulllength CMV, referred to as CMV173) and a minimal polyadenylation signal (49 bp, SPA) described by Ostedgaard and coworkers (30) and compared reporter gene expression levels with our standard rAAV vector carrying a full-length $\mathrm{CMV}$ and a BGHpA signal (rAAV-CMV173-Fluc and rAAV-CMV-Fluc, respectively) (Figure 3A). The latter expression cassette, in combination with CFTR $\Delta$ R, would exceed the rAAV packaging capacity. Fluc activity was compared following transduction of HEK293T cells with the respective rAAV vectors (Figure $3 \mathrm{~B}$ ). Even though rAAV-CMV173-Fluc showed a 35 -fold lower Fluc signal than the control vector (rAAV-CMV-Fluc), the signal was still 3-log higher than background (Figure 3B). Similar data were obtained when evaluating rAAV-CMV173-Fluc and rAAV-CMV-Fluc transduction in primary intestinal organoids (Figure 3C), demonstrating that a shorter expression cassette results in lower transgene expression levels, but opens the possibility to incorporate a larger cDNA, such as CFTRAR

\section{rAAV-Mediated CFTR $\Delta R$ Gene Transfer Rescues CFTR Activity in Human Intestinal Organoids}

After successful validation of rAAVCMV173-Fluc, we replaced the reporter genes with CFTR $\Delta \mathrm{R}$ to generate a therapeutic rAAV vector, referred to as rAAV-CFTR $\triangle \mathrm{R}$ with a genome size of 4,964 bp, which is just below the theoretical rAAV packaging limit of $5 \mathrm{~kb}$ (Figure 3D). rAAV-CMV173-Fluc was included as control (further referred to as rAAV control). Next, rAAV-CFTR $\Delta R$ was functionally validated in human CFTRdeficient organoids (E60X/4014delATTT; referred to as CF) (Figures 3E-3I). Even though the episomal nature of rAAV does not allow stable transduction of rapidly proliferating organoids, rAAV-CFTR $\Delta$ R resulted in FIS of transduced organoids at $t=120$ min (Figure 3G) compared with organoids transduced with rAAV control (Figure 3F), which corresponds to an average surface area increase of $13 \%$ (Figure $3 \mathrm{H}$ ), being fourfold higher than organoids treated with rAAV control (Figure 3I). Taken together, these data demonstrate that the engineered therapeutic $\mathrm{rAAV}-\mathrm{CFTR} \Delta \mathrm{R}$ vector is functional and that the ion transportinduced organoid swelling is CFTRdependent. Although the expression cassette is at the limit of the rAAV packaging capacity, data imply that intact genomes are incorporated into vector 
A

Organoid:

$\mathrm{CF}$
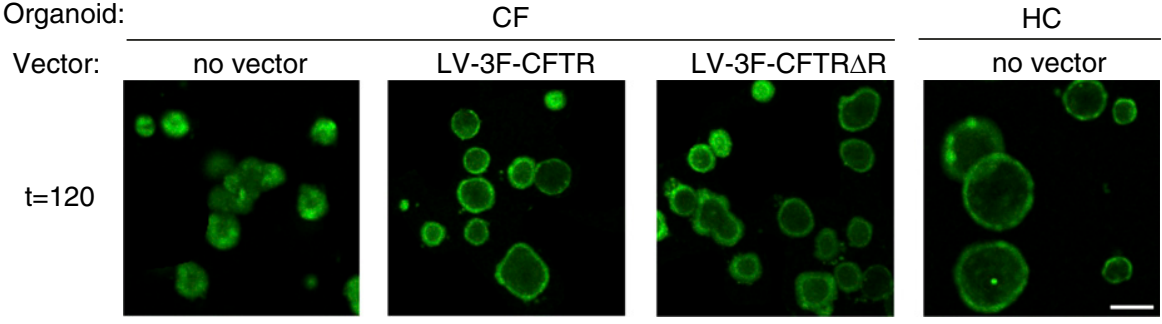

B

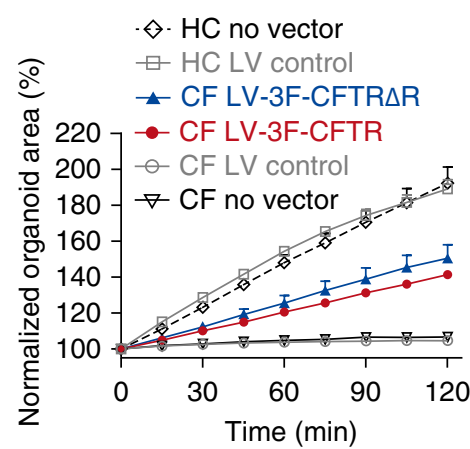

D

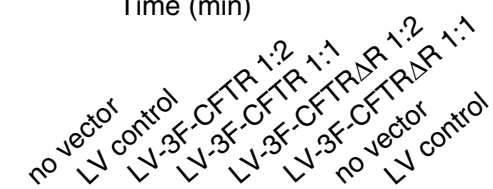

C

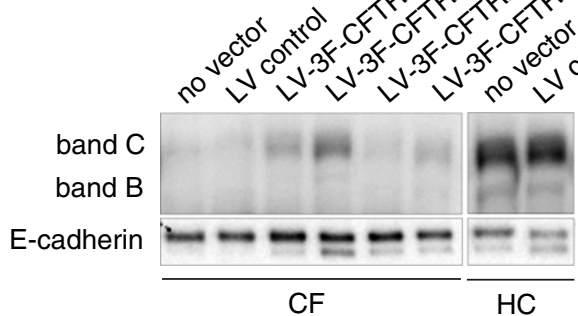

Figure 2. Truncated cystic fibrosis transmembrane conductance regulator (CFTR $\Delta \mathrm{R})$ restores chloride and fluid secretion in human intestinal organoids. (A) Confocal images of calcein green-labeled and forskolin-stimulated (120 min) organoids from a cystic fibrosis (CF) or healthy control $(\mathrm{HC})$ subject after transduction with a lentiviral vector (LV) encoding triple flag-tagged (3F) cystic fibrosis transmembrane conductance regulator (CFTR) or 3F-CFTR $\Delta$ R. Untransduced CF or $\mathrm{HC}$ organoids are taken along as a reference. In the CF panels, cell debris and unviable structures have been removed from the image following standard operating procedures. Scale bar $=100 \mu \mathrm{m}$. $(B)$ Forskolin-induced swelling of transduced organoids is expressed as the total organoid surface area increase relative to $t=0$ (normalized area) averaged from four independent wells. $(C)$ Forskolininduced swelling bars represent organoid swelling expressed as the area under the curve calculated from the time periods shown in B relative to the average $\mathrm{HC}$ response $(100 \%)$. The dashed lines correspond to the relative area under the curve for nontransduced CF (9.3\%) and nontransduced HC organoids (100\%), respectively. (D) Western blot analysis of CFTR and E-cadherin (loading control) in whole-cell lysates of organoids transduced with an LV expressing indicated CFTR or control constructs. All results are representative of at least three independent experiments and are presented as mean + SEM. CF organoids $=$ E60X/4015ATTTdel.

particles and allow efficient second strand DNA synthesis and transgene expression.

\section{rAAV2/5-CFTR $\Delta R$ Corrects the CF Phenotype in a $\Delta$ F508 Mouse Model} In a next step, we applied rAAV intranasally to $\Delta$ F508 mice (rAAV2/5-CFTR $\Delta \mathrm{R}$ and rAAV2/5-eGFP-P2A-Fluc, respectively) and assessed transgene expression by immunohistochemistry in nasal tissue (see Figure E3). CFTR $\Delta$ R expression was detected in the respiratory epithelium in a nonhomogeneous, patchy manner. In positively stained epithelial cells, CFTR $\Delta R$ was detected as a characteristic apical signal (see Figure E3A, black arrow) in rAAV2/5CFTR $\triangle R$-treated animals, whereas the signal was much lower in animals treated with rAAV control (see Figure E3B, orange arrow). This signal likely presents the detection of endogenous $\Delta$ F508-CFTR situated both in the cytoplasm and to a limited extent in the plasma membrane, as described by others for this mouse strain (32). However, a small part of the apical signal could be aspecific because low-level apical staining was occasionally observed in nasal tissue of CFTR knock-out mice (see Figure E3C).

In a final step, we evaluated functionality of our gene therapeutic approach in a $\Delta$ F508 mouse model (19). The experimental protocol is detailed in Figure 4. One week before treatment, NPD measurements were performed to assess residual activity of endogenous $\Delta$ F508-CFTR (Figure 4; see Figure E4, left recordings). We applied rAAV2/5CFTR $\Delta R(n=8)$ or rAAV2/5-eGFP-P2AfLuc, referred to as rAAV control, $(n=5)$ intranasally to CF mice (Figure 3D). Two to 4 weeks after vector administration, we assessed a phenotypic rescue by measuring changes in nasal transepithelial ion transport using NPD (Figure 4; see Figure E4, right recordings). NPD recordings after $\mathrm{rAAV} 2 / 5$-CFTR $\Delta \mathrm{R}$ treatment demonstrate a clear change in potential difference in response to low $\mathrm{Cl}^{-}$solution and to some extent after forskolin addition, which was partially inhibited by inh172 (Figure 4 demonstrates a NPD recording of a rAAV2/5-CFTR $\Delta$ R-treated animal; recordings of all animals are shown in Figure E4). Hyperpolarization after low $\mathrm{Cl}^{-}$and forskolin perfusion was taken as a main indicator to demonstrate a response to CFTR $\Delta \mathrm{R}$ gene transfer (33).

In the rAAV2/5-CFTR $\Delta$ R-treated group, five out of eight mice responded to low $\mathrm{Cl}^{-}$(Figure 5A). The highest change in potential difference value of this group measured 1 week before vector administration was taken as the cut-off value for positivity to score the effect of gene transfer. Mice that responded to treatment (five of eight) showed a significant hyperpolarization during low $\mathrm{Cl}^{-}$perfusion of $-5.8 \mathrm{mV}$ (median; range, -6.9 to $-3.4 ; \mathrm{n}=5$ ) compared with the group treated with $\mathrm{rAAV} 2 / 5$ control $(P=$ 0.008 ), indicating $\mathrm{Cl}^{-}$channel activity (Figure 5C). For comparison, reference values obtained in wild-type mice after low $\mathrm{Cl}^{-}$perfusion were $-5 \mathrm{mV}$ (median; range, -15.6 to $-1.2 ; \mathrm{n}=28$ ) (28). Additionally, a cumulative response to low $\mathrm{Cl}^{-}$and 
A

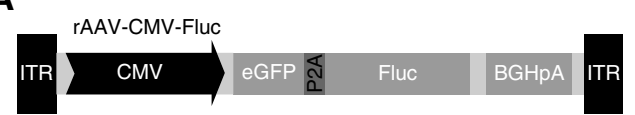

rAAV-CMV173-Fluc

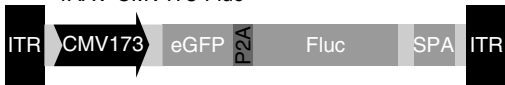

D

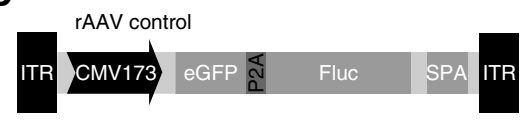

rAAV-CFTR $\triangle R$

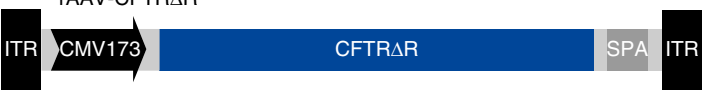

B

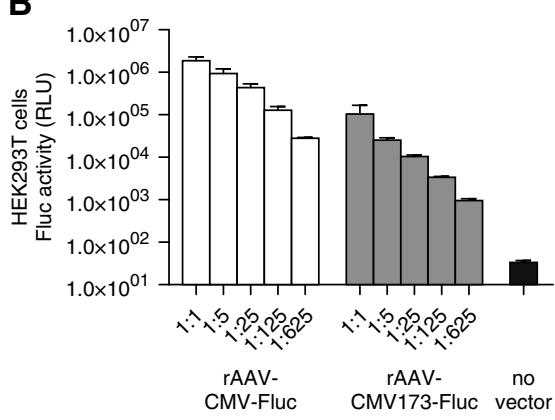

E

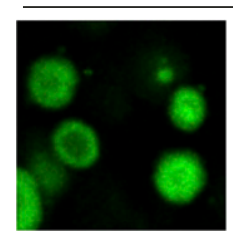

$\mathrm{t}=0$
C

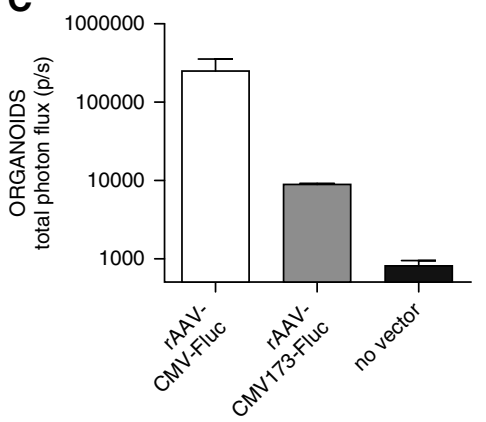

rAAV-CFTR $\triangle R$

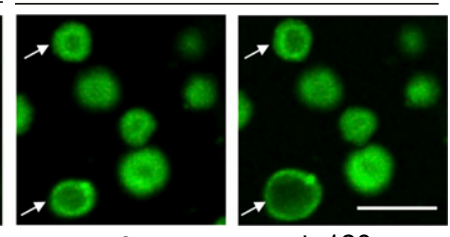

$\mathrm{t}=0$
F

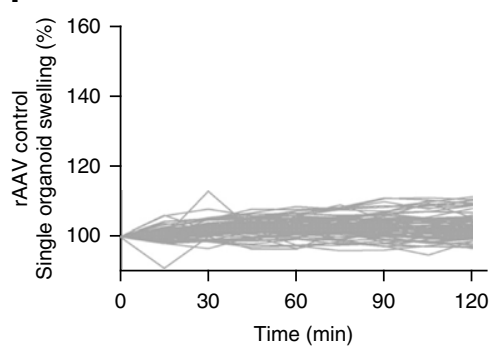

G

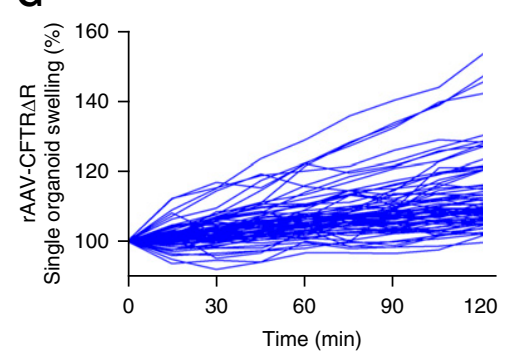

H

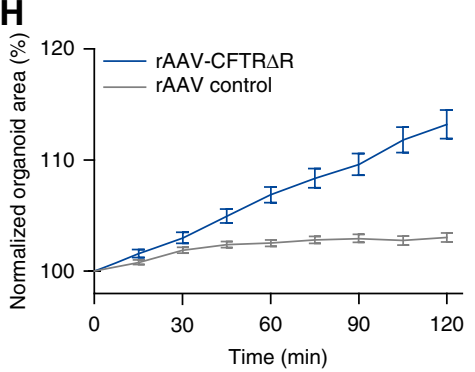

I

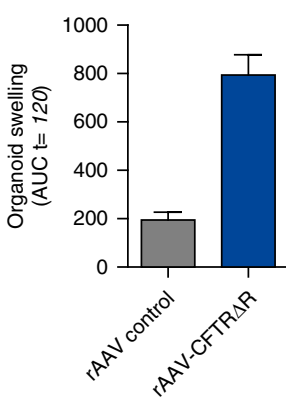

Figure 3. Recombinant adeno-associated viral vector (rAAV)-truncated cystic fibrosis transmembrane conductance regulator (CFTR $\Delta \mathrm{R})$ gene transfer rescues cystic fibrosis (CF) phenotype in CF organoids. (A) Comparison of following rAAV expression cassettes: rAAV-CMV-Fluc contains a cytomegalovirus (CMV) promoter (CMV, 583 bp), bovine growth hormone polyadenylation sequence (BGHpA, 215 bp), and reporter gene construct eGFP-P2A-Fluc. rAAV genome size (inverted terminal repeats [ITRs] included) $4.4 \mathrm{~kb}$. rAAV-CMV173-Fluc contains a shortened CMV (CMV173, 173 bp), minimal polyadenylation sequence (49 bp, SPA), and eGFP-P2A-Fluc (3.2 kb). (B) HEK293T were transduced with the respective rAAV2/5 vectors (1:1 dose: $8.0 \times 10^{9} \mathrm{GC} /$ well) and scored for Fluc activity in lysates (relative light units [RLU] normalized to total cell number). (C) Healthy control organoids were transduced with rAAV2/9 $\left(4.0 \times 10^{9} \mathrm{GC} /\right.$ well) and analyzed by bioluminescence imaging (photons/second $\left.[\mathrm{p} / \mathrm{s}]\right)$. (B and $\left.C\right)$ Background signal was determined in untransduced cells. (D) rAAV2/9 expression cassettes for forskolin-induced swelling (FIS) after transduction of CF organoids: rAAV-CMV173-Fluc ('rAAV control') and rAAV-CFTR $\Delta R$ ( $5 \mathrm{~kb}$ ), $3.0 \times 10^{8} \mathrm{GC} /$ well. ( $E$ ) Calcein green-labeled transduced organoids visualized before $(t=0 \mathrm{~min})$ and after $(t=120 \mathrm{~min})$ forskolin stimulation. Arrows indicate swelling. Scale $b a r=100 \mu \mathrm{m}$. ( $F$ and $\mathrm{G})$ Surface area increase relative to $t=$ 0 after stimulation (normalized area) of individual organoids after transduction with ( $F$ ) rAAV control or $(G)$ rAAV-CFTR $\Delta$ R. (H) FIS averaged from $F$ and G. (I) FIS of transduced organoids expressed as area under the curve (AUC) calculated from time periods in $H$ (baseline $=100 \%, t=120$ min). CF organoids $=$ E60X/4015ATT del. $(B, C$, and $/)$ Mean + SEM; $(H)$ mean \pm SEM. eGFP = enhanced green fluorescent protein .

forskolin perfusion was observed in five out of seven mice strengthening the previous observation (Figures 5B and 5D). Interestingly, a strong response to forskolin perfusion $(-6 \mathrm{mV})$ without initial hyperpolarization to low $\mathrm{Cl}^{-}$was observed in one animal (see Figure E4A, animal 7). In the rAAV2/5-CFTR $\Delta$ R-treated group, $\mathrm{Cl}^{-}$secretion could be inhibited to a larger extent compared with the control group (Figure 5E) $(P=0.03)$, underscoring the contribution of CFTR to the overall transepithelial ion transport. In summary, the ion transport defect in the nasal mucosa was restored by $\mathrm{rAAV} 2 / 5$-mediated CFTR $\Delta \mathrm{R}$ transfer in most treated $\Delta$ F508 mice.

\section{Discussion}

This study provides a robust proof-ofprinciple that $\mathrm{rAAV}$-mediated gene transfer of a truncated CFTR leads to functional rescue of CF. We demonstrated a significant improvement in CFTR channel activity in two complementary CF models: first, in human intestinal organoids; and second, in the $\Delta$ F508 mouse model, which allows in vivo assessment of CFTR correction by NPD, routinely used in patients. Since the discovery of CFTR in 1989 (34), the initial high expectations on gene therapy for CF were not met because of lack of persistent clinical benefit. A very recent clinical study by Alton and coworkers (35) demonstrated 


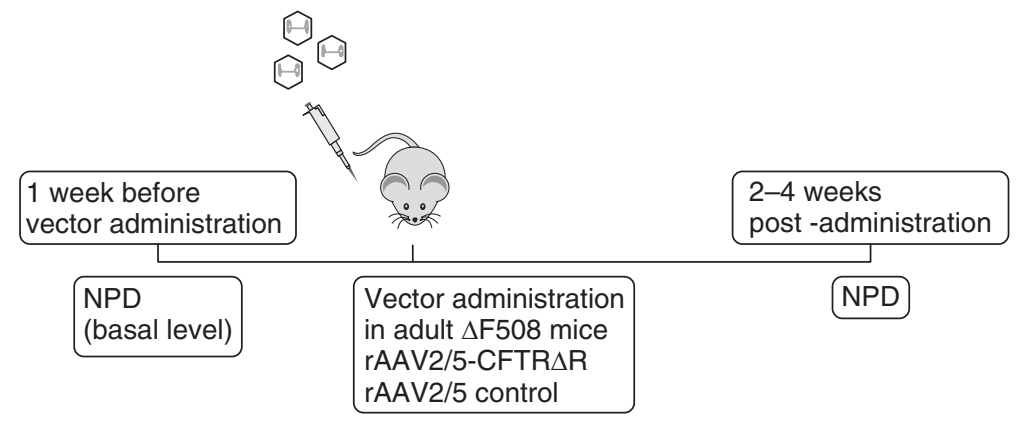

Before treatment

After rAAV2/5-CFTR $\Delta$ R treatment
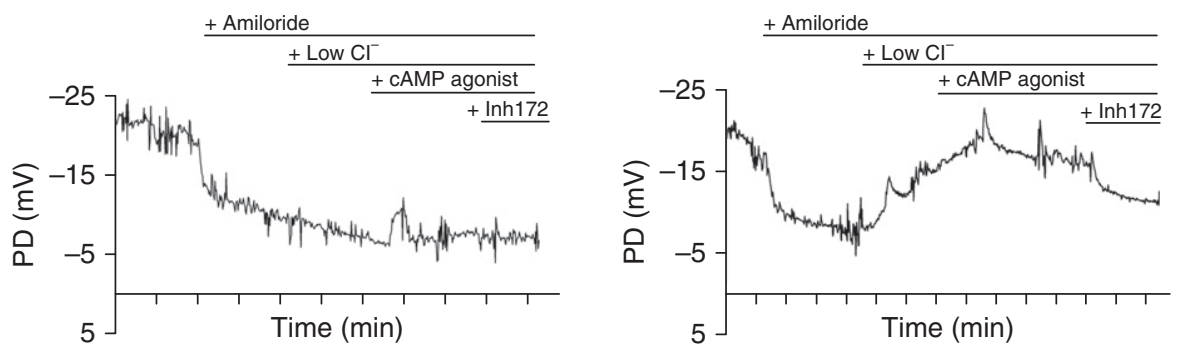

Figure 4. Recombinant adeno-associated viral vector (rAAV) 2/5-truncated cystic fibrosis transmembrane conductance regulator (CFTR $\Delta \mathrm{R})$ rescues ion transport defect in $\Delta$ F508 mouse nasal mucosa. (Top) Overview of the experimental set-up. Basal NPD was recorded 1 week before intranasal administration of rAAV2/5-CFTR $\Delta R$ or a rAAV2/5 control vector in adult mice homozygous for the $\Delta$ F508 mutation. NPD was measured 2-4 weeks postadministration. Bottom shows an example of an NPD recording before (left) and after rAAV2/5-CFTR $\Delta$ R treatment (right) for the same animal. Results are represented as the best responsive nostril. Each interval on the $x$-axis depicts a 1minute time frame. NPD = nasal potential difference.

that liposome-mediated airway delivery of CFTR cDNA stabilized lung function (measured by $\mathrm{FEV}_{1}$ ) in treated patients with $\mathrm{CF}$, whereas a further decline was observed in the placebo group, showing a first proof-of-concept of nonviral gene therapy to prevent further loss of lung function, a clinical hallmark of CF airway disease. Although the benefit achieved by this form of nonviral gene therapy is modest and at this stage too premature to become part of clinical care for patients with $\mathrm{CF}$, these results fuel further research on CF gene therapy. Liposomes are safe nonviral delivery vehicles that can transfer a large genetic cargo and allow repeated vector administration. However, transport from the cytoplasm to the nucleus presents a major rate-limiting step (reviewed in Reference 36), in contrast to viral vectors (37).

A first improvement compared with previous unsuccessful rAAV-based clinical trials for CF is the selection of the serotype. We opted for rAAV2/5, which efficiently transduces airway epithelia in mice and humans $(10-12,38)$, in contrast to rAAV2/ 2 used in the past (5). It is now known that receptors for that serotype are low to absent at the apical side of the airway epithelium, which could at least in part explain the limited success of rAAV2/2 (39). A second improvement is the use of an optimized expression cassette, which incorporates a truncated CFTR (CFTR $\Delta$ R) to allow addition of an external promoter (CMV173), which significantly enhanced gene expression. As a result, expression of $\mathrm{CFTR} \Delta \mathrm{R}$ in nasal tissue of $\mathrm{rAAV} 2 / 5$ treated $\Delta$ F508 mice was detected in our study. In contrast, previous rAAV2/2-based clinical trials for CF incorporated the full-length CFTR cDNA into the rAAV expression cassette. Packaging size restriction necessitated the use of the inverted terminal repeat promoter, the short but weak promoter present in the rAAV genome. The inability to detect CFTR expression in biopsies and the clinical failure in those trials may thus be caused by poor transgene expression $(5,6)$.

The use of a minigene for rAAV-based gene therapy, which has a packaging limit of approximately $5 \mathrm{~kb}$, is a strategy that has already been successfully applied in
Duchenne muscular dystrophy (40). In our study, CFTR $\Delta \mathrm{N}$ did not show any intrinsic channel activity (Figure 1D). However, previous studies demonstrated that this truncated form rescues the endogenous $\Delta$ F508-CFTR mutant by transcomplementation $(29,41)$, which can serve as an alternative gene therapy approach. However, although CFTR $\Delta \mathrm{R}$ was developed for a rAAV-based gene therapeutic approach, functionality in vivo has only been reported using adenoviralmediated gene transfer (13). In that perspective, our aim was to evaluate the therapeutic potential of $\mathrm{rAAV}-\mathrm{CFTR} \Delta \mathrm{R}$ as a novel treatment option for both CF airway and intestinal disease. Although stronger than the AAV inverted terminal repeat, the CMV173 promoter is weaker than the fulllength CMV promoter. This moderate activity may be an advantage for CF gene therapy because strong viral promoters result in marked overexpression, with some CFTR channels even being present in the basolateral membrane, thereby reducing transepithelial $\mathrm{Cl}^{-}$transport at the apical membrane (42). So we believe that the selection of the promoter contributed to our successful results.

Humans are naturally infected with AAV virus. Hence, preexisting immunity poses a major challenge for systemic $\mathrm{rAAV}$ based gene delivery (43-45). However, when rAAV is administered locally to for example the airways, the effect of preexisting neutralizing antibodies might be less pronounced. Different approaches are currently evaluated preclinically to reduce the effect of neutralizing antibodies, such as prior transduction with empty rAAV particles to deplete the serum or bronchoalveolar lavage fluid of rAAVspecific neutralizing antibodies (46) or capsid engineering to generate serologically distinct AAV serotypes (47). Each model used for preclinical validation of gene therapeutic approaches using rAAV requires prior selection of the optimal rAAV serotype for efficient transduction. As such, the rAAV2/5 preference in mouse does not necessarily carry through to humans (48). However, assuming that rAAV2/5 would be translated into the clinic, $40 \%$ of the human population is estimated to be seropositive and 3.2\% positive specifically for anti-AAV5 serum neutralizing factors (49-51). This prevalence is among the lowest of all natural AAV serotypes evaluated (49). 
A

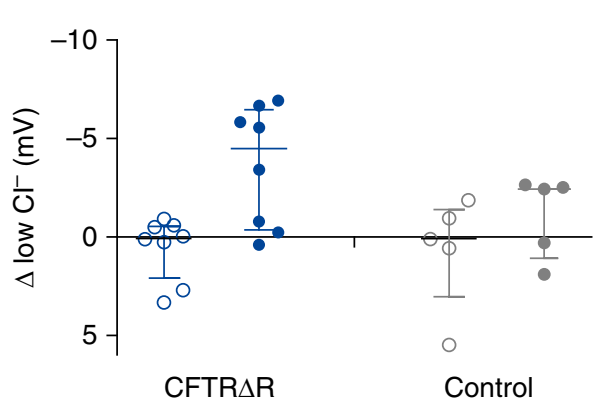

Before treatment

After rAAV2/5-CFTR $\Delta$ R treatment
B

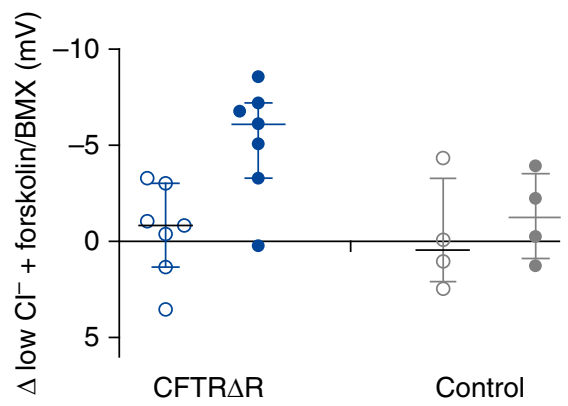

$\bigcirc$ Before treatment

- After rAAV2/5 control treatment c

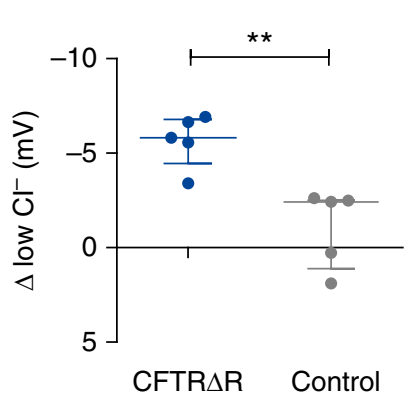

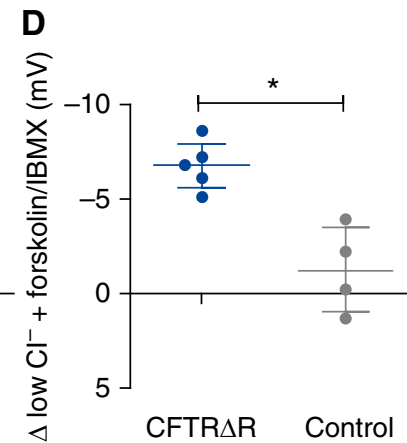

E

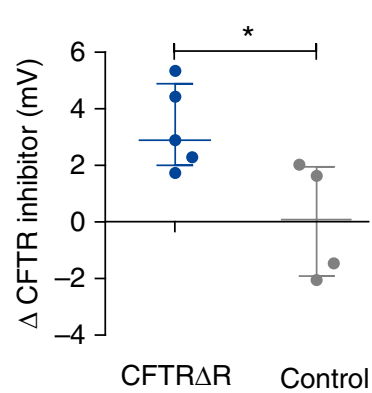

Figure 5. Nasal potential difference measurements demonstrate rescue after recombinant adenoassociated viral vector (rAAV) 2/5-truncated cystic fibrosis transmembrane conductance regulator $(\mathrm{CFTR} \Delta \mathrm{R})$ gene transfer. Adult mice homozygous for the $\Delta \mathrm{F} 508$ mutation were treated intranasally with rAAV2/5-CFTR $\Delta R(n=8)$ or $r A A V 2 / 5$ control vector $(n=5)$. At 2-4 weeks after administration, changes in transepithelial ion transport across nasal mucosa were assessed by NPD. (A) Response to low chloride perfusion. $(B)$ Cumulative response to low chloride and forskolin/3-isobutyl1-methylxanthine (IBMX) perfusion. ( $A$ and $B$ ) Basal values, recorded 1 week before vector administration, are presented at the left side of both graphs for each treatment group (open circles). (C) Comparison of the response to low chloride in animals that responded to rAAV2/5-CFTR $\Delta$ R gene transfer compared with the group treated with $\mathrm{rAAV} 2 / 5$ control vector. (D) Comparison of the cumulative response to low chloride and forskolin/IBMX perfusion after vector treatment in animals that responded to rAAV2/5-CFTR $\Delta R$ gene transfer compared with the group treated with $\mathrm{rAAV} 2 / 5$ control vector. The cut-off for positivity in animals that responded to rAAV2/5-CFTR $\Delta R$ gene transfer was determined as the highest value obtained in basal NPD measurements 1 week before treatment (open circles) for the respective group. (E) Effect of perfusion with CFTR inhibitor (inh172) evaluated after CFTR activation with low chloride and forskolin/IBMX perfusion and plotted as the difference in potential difference $(\triangle P D)$ between activation and inhibition. Measurements of individual animals were plotted as single values, and the median $\triangle \mathrm{PD}$ plus interquartile range per group is depicted. The response to vector treatment between the two groups was compared using a MannWhitney test for unpaired observations $\left({ }^{\star} P<0.05\right.$; $\left.{ }^{\star *} P<0.01\right)$. NPD $=$ nasal potential difference.

Compared with other AAV serotypes, AAV5 seroconversion occurs later in life (around 15-20 yr of age) (reviewed in Reference 52). This implies that a broader time window is available for rAAV2/5 gene therapy treatment in patients, situated between the decrease in maternal antiAAV5 antibodies found in newborns during the first few months after birth and the occurrence of AAV5 infection (reviewed in Reference 52).
Although rAAV is a mainly nonintegrating vector, it can provide sustained gene expression in different lowproliferative organs including the mouse lung $(11,38)$ and the liver, where systemic rAAV2/8 administration resulted in a reduction of the bleeding phenotype in hemophilia $B$ patients for more than 3 years $(44,45)$. Estimating the longevity of gene expression depends on the specific cell types transduced. For instance, ciliated airway epithelial cells, a primary target for CF gene therapy, are terminally differentiated and their half-life is estimated to be approximately 6 to even 17 months (53). Nevertheless, although the airway epithelium is a slowly proliferating tissue, repeated vector doses will most likely be necessary to ensure lifelong correction for specific diseases, such as CF. To that end, further exploration of approaches to circumvent an immune response to the AAV capsid is essential, such as serotype switching with a serologically distinct rAAV serotype (54), transient immunosuppression (55), vector administration to an immature immune system $(12,56)$, or prolonging the time period between vector administrations (11, $57)$. The safety of repeated rAAV2/2-CFTR doses has already been demonstrated in a clinical setting (6).

Apart from rAAV-based gene therapy for $\mathrm{CF}$, other viral vectors are currently being investigated to target the airways, such as LV (for a review, see Reference 58). Although prolonged gene expression can be obtained, it is yet to be elucidated if sustained LV-mediated gene expression results from transduced long-living terminally differentiated epithelial cells or from vector integration into stem cells (37, $59,60)$. An integrating vector is in theory capable of transducing airway stem cells. Many of these cells reside in specific anatomic niches (61); however, basal cells, one of the main stem cells described for adult airways, do not (62). They are located at the basal lamina of the pseudostratified respiratory epithelium and are thus not in contact with the lumen of the conducting airways. Therefore, the in vivo potential of transducing these different stem or progenitor populations via local airway delivery will have to be investigated for the specific viral vector system used.

Organoid experiments are valuable because they allow functional vector assessment in CF patient-derived material using a sensitive and quantitative FIS assay. The rescue we obtained in human CFTRdeficient organoids not only provides evidence that rAAV-CFTR $\Delta$ R can restore chloride and fluid transport, but at the same time highlights that the gastrointestinal CF phenotype can be corrected by gene therapy. The CF mouse model complements the organoid data because here a potential rescue of the $\mathrm{CF}$ 
phenotype can be assessed in vivo by NPD, a widely accepted biomarker used for evaluation of response to treatment in patients with CF $(28,63,64)$. Our results show a clear response to low $\mathrm{Cl}^{-}$and forskolin perfusion in most treated mice, underscoring the therapeutic potential of rAAV2/5-CFTR $\Delta R$. Importantly, the level of rescue after rAAVA2/5-CFTR $\Delta$ R gene transfer was comparable with the level of rescue after CFTR corrector treatment as measured by NPD (65). Variation in treatment response could be explained by differences in transduction efficiency between animals. This could affect NPD outcome depending on where exactly the measuring electrode was placed on the nasal epithelium.
In conclusion, this study provides a robust proof-of-principle that rAAVmediated gene transfer of a truncated CFTR leads to functional rescue of the $\mathrm{CF}$ phenotype in two complementary models: gastrointestinal pathology in human intestinal organoids, and in vivo assessment of CFTR correction in the nasal mucosa of CF mice. A next step is to investigate the therapeutic effect of rAAV-CFTR $\Delta \mathrm{R}$ in a larger animal model for $\mathrm{CF}$, such as the $\mathrm{CF}$ rat, ferret, or pig, because these models recapitulate human CF pathology more faithfully and allow a better assessment of the level of CFTR rescue required to ameliorate CF (66-69). If successful, gene therapy would drastically improve life expectancy and life quality of patients with CF by offering a definite cure for $\mathrm{CF}$ in a mutation-independent manner.

Author disclosures are available with the text of this article at www.atsjournals.org.

Acknowledgment: The authors thank Jooke Van der Veken, Wim Werckx, and Paulien Van de Velde for their excellent technical assistance. They acknowledge Lynda Ostedgaard and Michael Welsh from the Howard Hughes Medical Institute, University of lowa, for their kind gift of the pTM-CFTR $\Delta$ R and pAAV5-CMV173-CFTR $\Delta$ RSPA plasmids and Terence Flotte, University of Massachusetts Medical School, for the pAAVCB-dl264CFTR plasmid. They acknowledge the UPenn Vector Core founded by James $\mathrm{M}$. Wilson for the AAV2/5 and AAV2/9 packaging plasmids.

\section{References}

1. FDA. FDA approves new treatment for cystic fibrosis. 2015 [accessed 2015 Sept 2]. Available from: http://www.fda.gov/NewsEvents/ Newsroom/PressAnnouncements/ucm453565.htm

2. Wainwright CE, Elborn JS, Ramsey BW, Marigowda G, Huang X, Cipolli M, Colombo C, Davies JC, De Boeck K, Flume PA, et al.; TRAFFIC Study Group; TRANSPORT Study Group. Lumacaftor-ivacaftor in patients with cystic fibrosis homozygous for Phe508del CFTR. N Engl J Med 2015;373:220-231.

3. Amaral MD. Novel personalized therapies for cystic fibrosis: treating the basic defect in all patients. J Intern Med 2015;277:155-166.

4. Zabner J, Couture LA, Gregory RJ, Graham SM, Smith AE, Welsh MJ. Adenovirus-mediated gene transfer transiently corrects the chloride transport defect in nasal epithelia of patients with cystic fibrosis. Cell 1993;75:207-216.

5. Flotte TR, Zeitlin PL, Reynolds TC, Heald AE, Pedersen P, Beck S, Conrad CK, Brass-Ernst L, Humphries M, Sullivan K, et al. Phase I trial of intranasal and endobronchial administration of a recombinant adeno-associated virus serotype 2 (rAAV2)-CFTR vector in adult cystic fibrosis patients: a two-part clinical study. Hum Gene Ther 2003;14:1079-1088.

6. Moss RB, Rodman D, Spencer LT, Aitken ML, Zeitlin PL, Waltz D, Milla C, Brody AS, Clancy JP, Ramsey B, et al. Repeated adeno-associated virus serotype 2 aerosol-mediated cystic fibrosis transmembrane regulator gene transfer to the lungs of patients with cystic fibrosis: a multicenter, double-blind, placebo-controlled trial. Chest 2004;125:509-521.

7. Sheridan C. Gene therapy finds its niche. Nat Biotechnol 2011;29: 121-128.

8. Dismuke DJ, Tenenbaum L, Samulski RJ. Biosafety of recombinant adeno-associated virus vectors. Curr Gene Ther 2013:13:434-452.

9. Moss RB, Milla C, Colombo J, Accurso F, Zeitlin PL, Clancy JP, Spencer LT, Pilewski J, Waltz DA, Dorkin HL, et al. Repeated aerosolized AAVCFTR for treatment of cystic fibrosis: a randomized placebocontrolled phase 2B trial. Hum Gene Ther 2007;18:726-732.

10. Zabner J, Seiler M, Walters R, Kotin RM, Fulgeras W, Davidson BL, Chiorini JA. Adeno-associated virus type 5 (AAV5) but not AAV2 binds to the apical surfaces of airway epithelia and facilitates gene transfer. J Virol 2000;74:3852-3858.

11. Limberis MP, Wilson JM. Adeno-associated virus serotype 9 vectors transduce murine alveolar and nasal epithelia and can be readministered. Proc Natl Acad Sci USA 2006;103:12993-12998.

12. Carlon MS, Vidović D, Dooley J, da Cunha MM, Maris M, Lampi $Y$, Toelen J, Van den Haute C, Baekelandt V, Deprest J, et al. Immunological ignorance allows long-term gene expression after perinatal recombinant adeno-associated virus-mediated gene transfer to murine airways. Hum Gene Ther 2014;25:517-528.
13. Ostedgaard LS, Zabner J, Vermeer DW, Rokhlina T, Karp PH, Stecenko AA, Randak C, Welsh MJ. CFTR with a partially deleted R domain corrects the cystic fibrosis chloride transport defect in human airway epithelia in vitro and in mouse nasal mucosa in vivo. Proc Natl Acad Sci USA 2002;99:3093-3098.

14. Sato T, Stange DE, Ferrante M, Vries RG, Van Es JH, Van den Brink S, Van Houdt WJ, Pronk A, Van Gorp J, Siersema PD, et al. Long-term expansion of epithelial organoids from human colon, adenoma, adenocarcinoma, and Barrett's epithelium. Gastroenterology 2011; 141:1762-1772.

15. Sato T, van Es JH, Snippert HJ, Stange DE, Vries RG, van den Born M, Barker N, Shroyer NF, van de Wetering M, Clevers H. Paneth cells constitute the niche for Lgr5 stem cells in intestinal crypts. Nature 2011;469:415-418.

16. Jung $P$, Sato $T$, Merlos-Suárez $A$, Barriga FM, Iglesias $M$, Rossell $D$, Auer H, Gallardo M, Blasco MA, Sancho E, et al. Isolation and in vitro expansion of human colonic stem cells. Nat Med 2011;17: 1225-1227.

17. Dekkers JF, van der Ent CK, Beekman JM. Novel opportunities for CFTR-targeting drug development using organoids. Rare Dis 2013;1: e27112.

18. Dekkers JF, Wiegerinck CL, de Jonge HR, Bronsveld I, Janssens HM, de Winter-de Groot KM, Brandsma AM, de Jong NW, Bijvelds MJ, Scholte BJ, et al. A functional CFTR assay using primary cystic fibrosis intestinal organoids. Nat Med 2013;19:939-945.

19. van Doorninck JH, French PJ, Verbeek E, Peters $\mathrm{RH}$, Morreau $\mathrm{H}$, Bijman J, Scholte BJ. A mouse model for the cystic fibrosis delta F508 mutation. EMBO J 1995;14:4403-4411.

20. Grubb BR, Boucher RC. Pathophysiology of gene-targeted mouse models for cystic fibrosis. Physiol Rev 1999;79(Suppl. 1): S193-S214.

21. Vidovic D, Carlon M, da Cunha MF, Dekkers J, Hollenhorst M, Bijvelds $\mathrm{M}$, Van den Haute $\mathrm{C}$, Baekelandt V, de Jonge $\mathrm{H}$, Beekman J, et al. rAAV2/5 encoding truncated CFTR corrects CF phenotype in mouse nasal epithelium [abstract]. Hum Gene Ther 2014;25: A115-A116.

22. Vidovic D, Carlon M, Faria da Cunha M, Dekkers J, Hollenhorst M, Bijvelds M, Van den Haute C, Baekelandt V, de Jonge H, SermetGaudelus I, et al. rAAV2/5 encoding truncated CFTR rescues CF phenotype in $\triangle F 508$ mouse model [abstract]. Presented at the 12th ECFS Basic Science Conference. March 25-28, 2015, Algarve, Portugal. Poster 15.

23. Carlon M, Vidovic D, Dekkers J, Faria da Cunha M, Hollenhorst M, Bijvelds M, Van den Haute C, Baekelandt V, de Jonge H, De Boeck $\mathrm{K}$, et al. $\mathrm{rAAV} 2 / 5$ encoding a truncated CFTR rescues the CF 
phenotype in intestinal organoids and a CF mouse model [abstract]. J Cystic Fibros 2015;14(Suppl 1):S1. WS01.01.

24. Geraerts M, Michiels M, Baekelandt V, Debyser Z, Gijsbers R. Upscaling of lentiviral vector production by tangential flow filtration. J Gene Med 2005;7:1299-1310.

25. Carlon M, Toelen J, Van der Perren A, Vandenberghe LH, Reumers V, Sbragia L, Gijsbers R, Baekelandt V, Himmelreich U, Wilson JM, et al. Efficient gene transfer into the mouse lung by fetal intratracheal injection of rAAV2/6.2. Mol Ther 2010;18:2130-2138.

26. Vaandrager $A B$, Bajnath R, Groot JA, Bot AG, De Jonge HR. Ca2+ and cAMP activate different chloride efflux pathways in HT-29.cl19A colonic epithelial cell line. Am J Physiol 1991;261:G958-G965.

27. Hinzpeter A, Lipecka J, Brouillard F, Baudoin-Legros M, Dadlez M, Edelman A, Fritsch J. Association between Hsp90 and the CIC-2 chloride channel upregulates channel function. Am J Physiol Cell Physiol 2006;290:C45-C56.

28. Saussereau EL, Roussel D, Diallo S, Debarbieux L, Edelman A, SermetGaudelus I. Characterization of nasal potential difference in cftr knockout and F508del-CFTR mice. PLoS One 2013;8:e57317.

29. Cebotaru L, Woodward O, Cebotaru V, Guggino WB. Transcomplementation by a truncation mutant of cystic fibrosis transmembrane conductance regulator (CFTR) enhances $\Delta$ F508 processing through a biomolecular interaction. J Biol Chem 2013; 288:10505-10512.

30. Ostedgaard LS, Rokhlina T, Karp PH, Lashmit P, Afione S, Schmidt M, Zabner J, Stinski MF, Chiorini JA, Welsh MJ. A shortened adenoassociated virus expression cassette for CFTR gene transfer to cystic fibrosis airway epithelia. Proc Natl Acad Sci USA 2005;102: 2952-2957.

31. Kelly M, Trudel S, Brouillard F, Bouillaud F, Colas J, Nguyen-Khoa T, Ollero M, Edelman A, Fritsch J. Cystic fibrosis transmembrane regulator inhibitors CFTR(inh)-172 and GlyH-101 target mitochondrial functions, independently of chloride channel inhibition. $J$ Pharmacol Exp Ther 2010;333:60-69.

32. Wilke M, Buijs-Offerman RM, Aarbiou J, Colledge WH, Sheppard DN, Touqui L, Bot A, Jorna H, de Jonge HR, Scholte BJ. Mouse models of cystic fibrosis: phenotypic analysis and research applications. $J$ Cyst Fibros 2011;10:S152-S171.

33. De Boeck K, Derichs N, Fajac I, de Jonge HR, Bronsveld I, Sermet I, Vermeulen F, Sheppard DN, Cuppens H, Hug M, et al.; ECFS Diagnostic Network Working Group; EuroCareCF WP3 Group on CF diagnosis. New clinical diagnostic procedures for cystic fibrosis in Europe. J Cyst Fibros 2011;10:S53-S66.

34. Riordan JR, Rommens JM, Kerem B, Alon N, Rozmahel R, Grzelczak Z, Zielenski J, Lok S, Plavsic N, Chou JL, et al. Identification of the cystic fibrosis gene: cloning and characterization of complementary DNA. Science 1989;245:1066-1073.

35. Alton EW, Armstrong DK, Ashby D, Bayfield KJ, Bilton D, Bloomfield EV, Boyd AC, Brand J, Buchan R, Calcedo R, et al.; UK Cystic Fibrosis Gene Therapy Consortium. Repeated nebulisation of nonviral CFTR gene therapy in patients with cystic fibrosis: a randomised, double-blind, placebo-controlled, phase $2 \mathrm{~b}$ trial. Lancet Respir Med 2015;3:684-691.

36. Yin H, Kanasty RL, Eltoukhy AA, Vegas AJ, Dorkin JR, Anderson DG. Non-viral vectors for gene-based therapy. Nat Rev Genet 2014;15: 541-555.

37. Mitomo K, Griesenbach U, Inoue M, Somerton L, Meng C, Akiba E, Tabata T, Ueda Y, Frankel GM, Farley R, et al. Toward gene therapy for cystic fibrosis using a lentivirus pseudotyped with Sendai virus envelopes. Mol Ther 2010;18:1173-1182.

38. Sumner-Jones SG, Davies LA, Varathalingam A, Gill DR, Hyde SC. Long-term persistence of gene expression from adeno-associated virus serotype 5 in the mouse airways. Gene Ther 2006;13: 1703-1713.

39. Duan D, Yue Y, Yan Z, McCray PB Jr, Engelhardt JF. Polarity influences the efficiency of recombinant adenoassociated virus infection in differentiated airway epithelia. Hum Gene Ther 1998;9: 2761-2776.
40. Mendell JR, Campbell K, Rodino-Klapac L, Sahenk Z, Shilling C, Lewis S, Bowles D, Gray S, Li C, Galloway G, et al. Dystrophin immunity in Duchenne's muscular dystrophy. N Engl J Med 2010;363: 1429-1437.

41. Cebotaru L, Vij N, Ciobanu I, Wright J, Flotte T, Guggino WB. Cystic fibrosis transmembrane regulator missing the first four transmembrane segments increases wild type and DeltaF508 processing. J Biol Chem 2008;283:21926-21933.

42. Farmen SL, Karp PH, Ng P, Palmer DJ, Koehler DR, Hu J, Beaudet AL, Zabner J, Welsh MJ. Gene transfer of CFTR to airway epithelia: low levels of expression are sufficient to correct $\mathrm{Cl}$ - transport and overexpression can generate basolateral CFTR. Am J Physiol Lung Cell Mol Physiol 2005;289: L1123-L1130.

43. Manno CS, Pierce GF, Arruda VR, Glader B, Ragni M, Rasko JJ, Ozelo MC, Hoots K, Blatt P, Konkle B, et al. Successful transduction of liver in hemophilia by AAV-Factor IX and limitations imposed by the host immune response. Nat Med 2006; 12:342-347.

44. Nathwani AC, Tuddenham EG, Rangarajan S, Rosales C, Mclntosh J, Linch DC, Chowdary P, Riddell A, Pie AJ, Harrington C, et al. Adenovirus-associated virus vector-mediated gene transfer in hemophilia B. N Engl J Med 2011;365:2357-2365.

45. Nathwani AC, Reiss UM, Tuddenham EG, Rosales C, Chowdary P, McIntosh J, Della Peruta M, Lheriteau E, Patel N, Raj D, et al. Longterm safety and efficacy of factor IX gene therapy in hemophilia B. N Engl J Med 2014;371:1994-2004.

46. Mingozzi F, Anguela XM, Pavani G, Chen Y, Davidson RJ, Hui DJ, Yazicioglu M, Elkouby L, Hinderer CJ, Faella A, et al. Overcoming preexisting humoral immunity to AAV using capsid decoys. Sci Transl Med 2013;5:194ra92.

47. Zinn E, Pacouret S, Khaychuk V, Turunen HT, Carvalho LS, Andres-Mateos E, Shah S, Shelke R, Maurer AC, Plovie E, et al. In silico reconstruction of the viral evolutionary lineage yields a potent gene therapy vector. Cell Reports 2015;12: 1056-1068.

48. Flotte TR, Fischer AC, Goetzmann J, Mueller C, Cebotaru L, Yan Z, Wang L, Wilson JM, Guggino WB, Engelhardt JF. Dual reporter comparative indexing of rAAV pseudotyped vectors in chimpanzee airway. Mol Ther 2010;18:594-600.

49. Boutin S, Monteilhet V, Veron P, Leborgne C, Benveniste O, Montus $\mathrm{MF}$, Masurier $\mathrm{C}$. Prevalence of serum IgG and neutralizing factors against adeno-associated virus (AAV) types 1,2, 5, 6, 8, and 9 in the healthy population: implications for gene therapy using AAV vectors. Hum Gene Ther 2010;21:704-712.

50. Mingozzi F, Chen Y, Edmonson SC, Zhou S, Thurlings RM, Tak PP, High KA, Vervoordeldonk MJ. Prevalence and pharmacological modulation of humoral immunity to AAV vectors in gene transfer to synovial tissue. Gene Ther 2013;20:417-424.

51. Calcedo R, Vandenberghe LH, Gao G, Lin J, Wilson JM. Worldwide epidemiology of neutralizing antibodies to adeno-associated viruses. J Infect Dis 2009;199:381-390.

52. Grimm D, Kay MA. From virus evolution to vector revolution: use of naturally occurring serotypes of adeno-associated virus (AAV) as novel vectors for human gene therapy. Curr Gene Ther 2003;3: 281-304.

53. Rawlins EL, Hogan BL. Ciliated epithelial cell lifespan in the mouse trachea and lung. Am J Physiol Lung Cell Mol Physiol 2008;295: L231-L234.

54. Halbert CL, Rutledge EA, Allen JM, Russell DW, Miller AD. Repeat transduction in the mouse lung by using adenoassociated virus vectors with different serotypes. J Virol 2000;74: $1524-1532$

55. Halbert CL, Standaert TA, Wilson CB, Miller AD. Successful readministration of adeno-associated virus vectors to the mouse lung requires transient immunosuppression during the initial exposure. J Virol 1998;72:9795-9805.

56. Nivsarkar MS, Buckley SM, Parker AL, Perocheau D, McKay TR, Rahim AA, Howe SJ, Waddington SN. Evidence for contribution of CD4+ CD25+ regulatory T cells in maintaining immune tolerance to human factor IX following perinatal adenovirus vector delivery. J Immunol Res 2015;2015:397879. 
57. Auricchio A, O'Connor E, Weiner D, Gao GP, Hildinger M, Wang L, Calcedo R, Wilson JM. Noninvasive gene transfer to the lung for systemic delivery of therapeutic proteins. $J$ Clin Invest 2002;110: 499-504.

58. Griesenbach U, Alton EW. Moving forward: cystic fibrosis gene therapy. Hum Mol Genet 2013;22:R52-R58.

59. Sinn PL, Burnight ER, Hickey MA, Blissard GW, McCray PB Jr. Persistent gene expression in mouse nasal epithelia following feline immunodeficiency virus-based vector gene transfer. J Virol 2005;79: 12818-12827.

60. Griesenbach U, Inoue M, Meng C, Farley R, Chan M, Newman NK, Brum A, You J, Kerton A, Shoemark A, et al. Assessment of F/HNpseudotyped lentivirus as a clinically relevant vector for lung gene therapy. Am J Respir Crit Care Med 2012;186:846-856.

61. Weiss DJ. Intersection of gene therapy and progenitor cell biology in the lung. Mol Ther 2009;17:214-216.

62. Rock JR, Randell SH, Hogan BL. Airway basal stem cells: a perspective on their roles in epithelial homeostasis and remodeling. Dis Model Mech 2010;3:545-556.

63. Sermet-Gaudelus I, Girodon E, Sands D, Stremmler N, Vavrova V, Deneuville E, Reix P, Bui S, Huet F, Lebourgeois M, et al. Clinical phenotype and genotype of children with borderline sweat test and abnormal nasal epithelial chloride transport. Am J Respir Crit Care Med 2010;182:929-936.
64. De Boeck K, Kent L, Davies J, Derichs N, Amaral M, Rowe SM, Middleton $\mathrm{P}$, de Jonge $\mathrm{H}$, Bronsveld I, Wilschanski $\mathrm{M}$, et al.; European Cystic Fibrosis Society Clinical Trial Network Standardisation Committee. CFTR biomarkers: time for promotion to surrogate end-point. Eur Respir J 2013;41:203-216.

65. Odolczyk N, Fritsch J, Norez C, Servel N, da Cunha MF, Bitam S, Kupniewska A, Wiszniewski L, Colas J, Tarnowski K, et al. Discovery of novel potent $\triangle$ F508-CFTR correctors that target the nucleotide binding domain. EMBO Mol Med 2013:5:1484-1501.

66. Sun X, Sui H, Fisher JT, Yan Z, Liu X, Cho HJ, Joo NS, Zhang Y, Zhou W, Yi Y, et al. Disease phenotype of a ferret CFTR-knockout model of cystic fibrosis. J Clin Invest 2010;120:3149-3160.

67. Rogers CS, Stoltz DA, Meyerholz DK, Ostedgaard LS, Rokhlina T, Taft PJ, Rogan MP, Pezzulo AA, Karp PH, Itani OA, et al. Disruption of the CFTR gene produces a model of cystic fibrosis in newborn pigs. Science 2008;321:1837-1841.

68. Klymiuk N, Mundhenk L, Kraehe K, Wuensch A, Plog S, Emrich D, Langenmayer MC, Stehr M, Holzinger A, Kröner C, et al. Sequential targeting of CFTR by BAC vectors generates a novel pig model of cystic fibrosis. J Mol Med (Berl) 2012;90:597-608.

69. Tuggle KL, Birket SE, Cui X, Hong J, Warren J, Reid L, Chambers A, Ji $\mathrm{D}$, Gamber K, Chu KK, et al. Characterization of defects in ion transport and tissue development in cystic fibrosis transmembrane conductance regulator (CFTR)-knockout rats. PLoS One 2014;9: e91253. 